\title{
Michał Głuszkowski
}

\author{
Rec.: Helena Grochola-Szczepanek, \\ Język mieszkańców Spisza. Płeć jako czynnik różnicujący, \\ Kraków 2012, 370 ss.
}

W monografii Heleny Grocholi-Szczepanek poruszonych zostało wiele zagadnień leżących w sferze zainteresowań kilku subdyscyplin językoznawstwa: dialektologii, socjolingwistyki i lingwistyki genderowej. Tytuł Język mieszkańców Spisza. Płeć jako czynnik różnicujący odzwierciedla jedynie część z nich, choć jak podkreśla autorka, miał on przede wszystkim wskazywać na dwuczęściową kompozycję pracy. W części pierwszej, która ma charakter wprowadzający, opisana została zastosowana metodologia, historyczne, społeczno-kulturowe uwarunkowania oraz aktualna sytuacja socjolingwistyczna gwary spiskiej. Z kolei druga część książki odnosi się do szeroko rozumianych relacji języka i płci, zarówno na poziomie zjawisk językowych, np. wykładniki płci w mowie mieszkańców spiskich wsi, jak i na płaszczyźnie pragmatyczno-socjolingwistycznej - różnice w zachowaniach językowych kobiet i mężczyzn. W ten sposób praca H. Grocholi-Szczepanek wpisuje się w coraz liczniej reprezentowany w ostatnich latach nurt badań zagadnienia płci w języku. Kwestie poruszane w obydwu częściach książki nie stanowią dla autorki novum, ponieważ jej dotychczasowe badania dialektów polskich, w tym również gwary spiskiej, a także problematyki męskich i żeńskich nazw w języku ludowym, rodzaju gramatycznego czy językowego obrazu mężczyzn i kobiet zaowocowały szeregiem publikacji w ciągu ostatnich kilkunastu lat. 
W rozdziale I przybliżone zostały przyjęte metody i techniki badawcze. Na uznanie zasługuje szeroki - kilkuletni zakres czasowy badań i zróżnicowanie sposobów gromadzenia materiału językowego i socjolingwistycznego. Oprócz najczęściej stosowanych w badaniach dialektologicznych wywiadów indywidualnych H. Grochola-Szczepanek przeprowadziła również badania ankietowe wśród spiskiej młodzieży w końcowych klasach gimnazjów, wykorzystała istniejące zapisy tekstów gwarowych oraz opracowania na ich temat. Najistotniejsze wydaje się jednak uzupełnienie tego repertuaru o metodę zapożyczoną z badań społecznych - zogniskowane wywiady grupowe, tzw. fokusowe, których istotą jest moderowana przez badacza dyskusja kilkuosobowego grona przedstawicieli opisywanej społeczności. Wywiady fokusowe stosowane są w socjologii jakościowej, w celu poznania opinii wyselekcjonowanej grupy na określony temat, jak choćby wprowadzanego na rynek produktu lub tematów drażliwych i kontrowersyjnych, np. rzeczywistego stosunku do mniejszości narodowych. Na ile uzasadnione jest przeniesienie metody badawczej z innej dyscypliny? Ze względu na charakter badań $\mathrm{H}$. Grocholi-Szczepanek i wyznaczone przez nią cele obejmujące m.in. społeczno-kulturowe i psychologiczne uwarunkowania zjawisk zachodzących we współczesnej gwarze spiskiej, różnice w komunikowaniu się mężczyzn i kobiet oraz analizę wizerunku obydwu płci w językowym obrazie świata, posłużenie się metodą zogniskowanego wywiadu grupowego jest jak najbardziej uprawomocnione. Ponieważ osoby wyznaczone do udziału w wywiadach znały autorkę już wcześniej z jej rodzinnej miejscowości lub została ona im polecona przez znajomych, a wywiady odbywały się w gwarze spiskiej, sytuacja wywiadu fokusowego była na tyle swobodna, że możliwe było zarejestrowanie zachowań językowych i społecznych niedostępnych w bardziej sformalizowanych warunkach wywiadu indywidualnego z wyraźnie wyznaczonymi rolami badacza i badanego.

Należy zauważyć, że wprowadzenie do badań języka mieszkańców Spisza wywiadów fokusowych stanowi interesujący przykład reakcji uczonego na zmianę sytuacji badawczej, a ściślej rzecz ujmując, dostosowania metodologii do zastanej rzeczywistości. Prowadząc wywiady indywidualne na szereg tematów, m.in. o wsi, regionie i ich mieszkańcach, pracy i szkole, rodzinie, tradycji i wierzeniach oraz kobietach i mężczyznach (określenia, ubiór, charakter, rola w rodzinie i in.), H. Grochola-Szczepanek zauważyła, że włączanie się do tych rozmów domowników informatora, zwłaszcza w rodzinach wielopokoleniowych, daje ciekawe, wcześniej nieoczekiwane efekty. Z kolei ostatnia z metod pozyskiwania materiału empirycznego - badania ankietowe miały posłużyć określeniu stopnia znajomości leksyki gwarowej i stopnia jej wykorzystania przez młodych Spiszan oraz społeczno-demograficzne uwarunkowania zróżnicowań w tym zakresie. 
Przedstawiona w rozdziale II społeczno-kulturowa i historyczna charakterystyka Spisza jest zwięzła i zawiera podstawowe dane na temat regionu i najważniejszych faktów z jego historii, zabytków, architektury, tradycyjnej gospodarki, ubioru, folkloru i obrzędowości, a także informacje o liczbie mieszkańców w poszczególnych miejscowościach z uwzględnieniem kryterium płci, strukturze zatrudnienia i wykształcenia. Podobnie skrótowy charakter ma kolejny rozdział poświęcony stanowi gwary spiskiej na początku XXI wieku. W tym krótkim, bo liczącym 16 stron fragmencie książki omówione zostały dotychczasowe badania gwary Spisza, sytuacja socjolingwistyczna i ostatnie zmiany w sferze leksyki, a czysto lingwistycznej charakterystyce badanego języka z perspektywy autorka poświęciła zaledwie 3 strony, na których wymienione zostały główne cechy gwary spiskiej. W pracy o charakterze socjolingwistycznym szczegółowa analiza zjawisk językowych nie jest konieczna, ale pierwsza część tytułu omawianej książki Język mieszkańców Spisza pozwala oczekiwać obszerniejszego opisu badanej gwary.

Ostatni rozdział pierwszej części monografii H. Grocholi-Szczepanek stanowi przeprowadzona na podstawie wyników badań ankietowych analiza roli czynników demograficzno-społecznych w zróżnicowaniu mowy opisywanej społeczności. Wychodząc z założenia, że leksykon jest najbardziej podatnym na zmiany elementem systemu językowego, autorka postanowiła na tej podstawie ukazać zewnętrzne uwarunkowania zmian językowych. W tekście przedstawione zostały procentowe rozkłady odpowiedzi na pytanie o znaczenie gwarowych leksemów i ich używanie z uwzględnieniem kryterium płci. Ponieważ ankieta zawierała również pytania o stosowanie spiskiej leksyki gwarowej przez rodziców i dziadków respondentów, oprócz różnic w zachowaniach językowych dziewcząt i chłopców uchwycone zostały także zmiany pokoleniowe. Autorka zbadała także terytorialny rozkład wyników ankiety, dzięki czemu udało jej się stwierdzić zależność zakresu zachowania tradycyjnej leksyki gwarowej od stopnia izolacji społecznej miejscowości. Mieszkańcy wsi oddalonej od innych miejscowości, z utrudnionym dojazdem, wykazali znacznie wyższy poziom znajomości lokalnej gwary niż badani zamieszkujący w wioskach lepiej skomunikowanych z ośrodkami miejskimi. Obszerna, szczegółowa i wielowymiarowa analiza demograficznych uwarunkowań zróżnicowań leksykalnych nie tylko dostarcza wielu cennych informacji na temat aktualnego stanu gwary spiskiej, ale może również stanowić inspirację metodologiczną w badaniach języka wsi $\mathrm{w}$ innych regionach.

Drugą część monografii H. Grocholi-Szczepanek rozpoczynają rozważania teoretyczne na temat lingwistycznych badań nad płcią. Wychodząc od zróżnicowania zachowań społecznych ze względu na kryterium płci opisywanego 
w klasycznych już dziś pracach socjologicznych i antropologicznych, autorka przeszła do problematyki rozwoju gender studies w trzech ostatnich dekadach XX w. i ich lingwistycznej gałęzi. W językoznawczych badaniach nad płcią H. Grochola-Szczepanek wyróżniła analizy prowadzone na poziomie langue - dotyczące odzwierciedlenia różnic płci w języku, np. asymetrie językowego obrazu mężczyzn i kobiet, nazwy tytułów lub zawodów oraz badania poziomu parole - różnic pomiędzy wypowiedziami kobiet i mężczyzn. Niestety podział ten nie do końca znalazł odzwierciedlenie $\mathrm{w}$ analizie prowadzonej przez autorkę. Wymieniane we wstępie prace poświęcone zagadnieniom genderowym w języku, jak również opisywane przykłady tego typu badań dotyczą poziomu langue, czyli tego, jak język reaguje na kryterium płci. Tymczasem analizy sfery parole, w których płeć potraktowana jest jako zmienna niezależna i skorelowana ze zmiennymi zależnymi o naturze językowej należą do rzadkości nie tylko w polskim językoznawstwie ${ }^{1}$. Najczęściej dotyczą one tzw. stylu kobiecego i nawiązują do sformułowanych przez Robin Lakoff tez o języku kobiet, w myśl których cechuje go większa niż u mężczyzn poprawność fonetyczna i gramatyczna, częstsze stosowanie form grzecznościowych i większa ilość specjalistycznego słownictwa z zakresu tradycyjnie kobiecych dziedzin życia. H. Grochola-Szczepanek zauważyła, że podejście R. Lakoff zostało wielokrotnie skrytykowane z powodu braku uwzględnienia przez amerykańską badaczkę podstawowych uwarunkowań społecznych, jednak nie przedstawiła dla wspomnianej teorii metodologicznej alternatywy. Tezy R. Lakoff na temat języka obydwu płci zostały jedynie uzupełnione o podobne, równie nieostre ${ }^{2}$ stwierdzenia autorstwa innej amerykańskiej socjolingwistki - Deborah Tannen. Na szczęście, w analizie różnic między mową kobiet i mężczyzn w spiskich wsiach H. Grochola-Szczepanek skupiła się na faktycznie zarejestrowanych zachowaniach językowych i uniknęła ilustrowania ogólnikowych charakterystyk innych uczonych. Obserwacje te dotyczyły większej otwartości kobiet na rozmowę już przy pierwszym kon-

1 Nawet w największych światowych czasopismach poświęconych problemom socjolingwistyki i socjologii języka publikacje poświęcone zróżnicowaniu zachowań językowych ze względu na płeć mówiącego pojawiają się sporadycznie; Zob. m.in. D. Brouwer, M. Gerritsen, D. de Haan, Speech differences between women and men: on the wrong track?, „Language in Society" 8, 1979, s. 33-50; L. Hirsch man n. Female-male differences in conversational interaction. „Language in Society” 23, 1994, s. 427-442.

${ }^{2}$ W cytowanych przez H. Grocholę-Szczepanek charakterystykach języka kobiet i mężczyzn (s. 127, 135) R. Lakoff i D. Tannen pojawiają się sformułowania „raczej”, „zwykle”, które na tyle osłabiają precyzję tych opisów, że nie wnoszą one pod względem poznawczym do badań zróżnicowań zachowań językowych obydwu płci więcej niż wiedza potoczna w tym zakresie. 
takcie z badaczką, mniejszej pewności w sądach niż u mężczyzn, znajomości słownictwa gwarowego, odzwierciedlającej podziały na tradycyjnie męskie i kobiece sfery życia, a także stosowania przez informatorki bezokolicznikowej formy czasu przyszłego, np. bedym ścinać, podczas gdy mężczyźni używali form osobowych, np. bedym oroł. Pewne różnice występowały również w zakresie fonetyki gwarowej, jednak jak przyznała sama autorka, ocena skali tego zjawiska wymaga dalszych badań.

Okazuje się, że w części poświęconej różnicom w mowie kobiet i mężczyzn opisanych zostało jedynie kilka zjawisk i cech językowych, które na takie zróżnicowania wskazują. W innych wypadkach różnice nie zostały wykazane lub miały charakter pokoleniowy, a nie genderowy. Dlatego trudno oprzeć się wrażeniu, że w zakresie analizy sfery parole, czyli różnic w komunikowaniu się kobiet i mężczyzn, tytuł pracy Język mieszkańców Spisza. Płeć jako czynnik różnicujący i wstęp obiecują znacznie więcej, niż autorce udało się zrealizować. Płeć w monografii H. Grocholi-Szczepanek nie występuje (lub występuje w bardzo ograniczonym zakresie) jako czynnik różnicujący zachowania językowe, za to jej obecność w języku jest analizowana szczegółowo.

Dlatego zdecydowanie lepiej przedstawia się realizacja pozostałych założeń autorki: charakterystyka językowych wykładników żeńskości i męskości oraz wizerunku obydwu płci w językowym obrazie świata spiskiej wsi, którym to problemom zostały poświęcone dwa ostatnie i najbardziej obszerne rozdziały omawianej monografii. W części dotyczącej kodowania informacji o płci w gwarze Spisza analizie zostały poddane nazwy własne i ich słowotwórstwo, rzeczowniki pospolite (w tym także nazwy grup mężczyzn i kobiet), męskie i żeńskie nazwy rodzinne, a także sposoby odzwierciedlenia płci przy pomocy rodzaju gramatycznego. Każda z opisywanych kwestii została zilustrowana bogatym materiałem językowym w postaci przykładów wypowiedzi w określonym kontekście oraz usystematyzowanych w tabelach, np. przedstawiających nazwy rodzinne w zależności od stopnia powinowactwa. Równie bogaty pod względem materiałowym jest ostatni rozdział, w którym problematyka językowego obrazu kobiety i mężczyzny na wsi została potraktowana przez autorkę dość szeroko. Wyróżnione zostały trzy główne pola semantyczne, ukazujące przedstawicieli obydwu płci: a) w różnych okresach życia - od dzieciństwa, poprzez młodość i dojrzałość, po starość; b) ze względu na pozycję w społeczeństwie wiejskim, m.in. w ramach opozycji swojskość-obcość, otwartość-izolacja, stateczność-impulsywność; c) ze względu na cechy fizyczne, takie jak wzrost, tusza, atrakcyjność fizyczna, ale również narządy płciowe i stany fizjologiczne. Podobnie jak w części poświęconej wykładnikom płci w strukturze języka, również w charakterystyce językowego obrazu kobiet i mężczyzn 
autorka uwzględniła kontekst społeczno-kulturowy poszczególnych zjawisk na poziomie języka.

Monografię H. Grocholi-Szczepanek uzupełnia aneks zawierający informacje na temat używanego podczas wywiadów kwestionariusza oraz kilkudziesięciostronicowy wybór tekstów gwarowych. Wśród nich znalazły się zarówno przykłady wywiadów indywidualnych, jak i grupowych, co pozwala czytelnikowi na lepsze zapoznanie się z zastosowanymi przez autorkę metodami. Orientację w materiale ułatwia indeks określeń gwarowych związanych z płcią, które pojawiły się w pracy. Choć zagadnienie zróżnicowania zachowań językowych ze względu na płeć wymaga sprecyzowania założeń teoretycznych i pogłębienia samej analizy, należy podkreślić, że pozostałe cele badawcze zostały w pełni zrealizowane. Książka Język mieszkańców Spisza. Płeć jako czynnik różnicujacy jako rzetelne i bogate pod względem materiałowym studium socjolingwistyczne zasługuje na uwagę nie tylko językoznawców, ale i przedstawicieli innych dyscyplin. 